\title{
Heavy metal in honey bees, honey and pollen produced in different locations of Konya province in Turkey
}

Huseyin Bayir

Selcuk University: Selcuk Universitesi

Ali Aygun ( $\square$ aaygun@selcuk.edu.tr)

Selcuk University https://orcid.org/0000-0002-0546-3034

\section{Research Article}

Keywords: Heavy metal, honey, honey bee, pollen

Posted Date: March 1st, 2022

DOI: https://doi.org/10.21203/rs.3.rs-1302296/v1

License: (c) (7) This work is licensed under a Creative Commons Attribution 4.0 International License. Read Full License 


\section{Abstract}

We investigated the levels of heavy metals in honey bee, honey and pollen samples obtained from different locations of Konya City in Turkey. Five honey-bee colonies were placed in eight different locations, four of them around the city center and four in rural areas, in the province of Konya City in Turkey. Heavy metal ( $\mathrm{Cd}, \mathrm{Cr}, \mathrm{Cu}, \mathrm{Fe}, \mathrm{Mn}, \mathrm{Ni}, \mathrm{Pb}$, and $\mathrm{Zn}$ ) levels were determined in honey-bee, honey, and pollen samples taken from these colonies, with comparison between samples from urban and rural areas. The values of $\mathrm{Cd}$ and $\mathrm{Pb}$ in honey samples and those of $\mathrm{Cd}$ in pollen samples did not differ significantly among the locations. All heavy metal values of honey bee samples were lower in rural areas than in urban areas $(P<0.05)$. Significant statistical differences were determined for $\mathrm{Cr}, \mathrm{Cu}, \mathrm{Fe}, \mathrm{Mn}, \mathrm{Ni}$, and $\mathrm{Zn}$ values of honey and pollen samples among the locations $(\mathrm{P}<0.05)$. Heavy metal values of honey and pollen samples obtained from different locations were in agreement with the International Food Standard values.

\section{Introduction}

Beekeeping is sometimes practiced in places close to or within residential and industrial areas. Apiaries that are not suitable for bee colonies and mistakes made in production deteriorate the natural characteristics and quality of bee products.

Environmental problems that arise with population growth, urbanization, industrialization, and changing consumption habits are increasingly common. For example, heavy metals released into the air in the form of dust and ash from various sources accumulate on plants (Taha et al. 2017) and cause the pollution of soil and water resources by precipitation or by sedimentation. In addition, heavy metals in wastewater, chemicals used in agriculture, and fertilizers can also affect animals and humans via accumulation on the food chain (Duruibe et al. 2007; Squadrone et al. 2020; Türközü and Şanlıer 2014; Yılmaz 1996).

Heavy metals enter the bodies of animals and humans via ingestion (food and water), respiration, and the skin; they can be classified as essential and nonessential (Özbolat and Abdullah 2016). For example, some elements such as copper, zinc, iron, manganese, and selenium are essential for body development and proper functioning. On the other hand, non-essential elements, such as lead, cadmium, and mercury can cause various disorders by accumulating in the body and affecting the biological structure, even at low concentrations (Tuzen et al. 2007; Uluozlu et al. 2007).

To determine the environmental pollution of a region, living organisms (bioindicators or biomonitors) that show different sensitivities to various pollutants can be used (Yılmaz 1996). In this sense, honey-bees and bee products can contain residues of pollutants, making them important indicators of environmental pollution (Ahmida et al. 2012; Bogdanov 2008; Porrini et al. 2003; Taha et al. 2017; Zhelyazkova 2012).

Honey-bees can easily live in different environmental conditions, can be kept easily, have a short life cycle and a high reproductive rate, and as a colony, they can be transported to any place. They move around the apiary within an area of approximately $7 \mathrm{~km}^{2}$ in search of food, and samples for analysis can be taken during flight activity (Conti and Botrè 2001; Leita et al. 1996; Perugini et al. 2011).

Bee and bee products can be contaminated with pollutants from different sources, and the contamination may differ according to the environmental conditions of the beekeeping area (Costa-Silva et al. 2011; Hennessy et al. 2010; Pohl et al. 2011). Demirezen and Aksoy (2005) and Bogdanov (2008) reported that heavy metal accumulation is higher in bee products obtained from industrial regions and areas with heavy vehicle traffic, especially those close to large settlements and garbage incinerators.

In this context, this study compared the heavy metal contents of honey bees, honey, and pollen obtained from places close to residential and industrial areas with those obtained from rural areas and determined whether honey and pollen taken from these areas pose a problem in terms of food safety.

\section{Materials And Methods Sampling Sites (Locations)}

The study was carried out in Konya region, Turkey, in 2018. Five honey bee colonies (40 in total) were placed in eight different multifloral locations, four of which were around the city center (L1 to L4) and four in the rural area (L5 to L8) (Fig. 1).

The locations had the following characteristics:

L1: $38^{\circ} 02^{\prime} 05^{\prime \prime} \mathrm{N}, 32^{\circ} 30^{\prime} 10^{\prime \prime} \mathrm{E}, 1,180 \mathrm{~m}$. On the northern side of the city and in the prevailing wind direction of the city, 1,210 $\mathrm{m}$ away from and west of the highway. There is very little agricultural activity in the vicinity, and there are no industrial facilities.

L2: $37^{\circ} 55^{\prime} 12^{\prime \prime} \mathrm{N}, 32^{\circ} 26^{\prime} 10^{\prime \prime} \mathrm{E}, 1,140 \mathrm{~m}$. On the northwestern side of the city and in the prevailing wind direction of the city, 4,300 $\mathrm{m}$ away from and north of the highway. There is very little agricultural activity in the vicinity, and there are no industrial facilities.

L3: $37^{\circ} 51^{\prime} 07^{\prime \prime} \mathrm{N}, 32^{\circ} 33^{\prime} 33^{\prime \prime} \mathrm{E}, 1,010 \mathrm{~m}$. Southeast of the city, southwest of the industrial regions; the prevailing wind direction is from the industrial regions. This site is $1,800 \mathrm{~m}$ away from and south of one highway and 1,300 $\mathrm{m}$ away from and east of another highway. Agricultural activities are carried out in the surrounding area.

L4: $37^{\circ} 49^{\prime} 12^{\prime \prime} \mathrm{N}, 32^{\circ} 28^{\prime} 45^{\prime \prime} \mathrm{E}, 1,027 \mathrm{~m}$. On the southern side of the city; the prevailing wind direction is from the city side. It is $1,000 \mathrm{~m}$ away from and south of one highway and 3,400 m away from and west of another highway. Although not nearby, there are industrial facilities in the prevailing wind direction, and agricultural activities are carried out around it. 
L5: $37^{\circ} 28^{\prime} 16^{\prime \prime} \mathrm{N}, 31^{\circ} 48^{\prime} 56^{\prime \prime} \mathrm{E}, 1,131 \mathrm{~m}$. This site is 4,600 $\mathrm{m}$ away from and northwest of the highway. There is only one aluminum-processing plant at a distance of $3,750 \mathrm{~m}$ in the southeast, and there is little agricultural activity in its vicinity.

L6: $37^{\circ} 42^{\prime} 05^{\prime \prime} \mathrm{N}, 33^{\circ} 31^{\prime} 20^{\prime \prime} \mathrm{E}, 1,003 \mathrm{~m}$. This site is $1,400 \mathrm{~m}$ away from and south of the highway. There are no industrial facilities in the vicinity; agricultural activities are carried out sparsely.

L7: $38^{\circ} 05^{\prime} 07^{\prime \prime} \mathrm{N}, 32^{\circ} 16^{\prime} 45^{\prime \prime} \mathrm{E}, 1,630 \mathrm{~m}$. In the vicinity of this site, there is very little agricultural activity, and there are no highways, industrial facilities, etc. nearby.

L8: $36^{\circ} 58^{\prime} 38^{\prime \prime} \mathrm{N}, 32^{\circ} 22^{\prime} 51^{\prime \prime} \mathrm{E}, 1,775 \mathrm{~m}$. In the vicinity of this site, there is very little agricultural activity, and there are no highways, industrial facilities, etc. nearby.

The prevailing wind direction in Konya is north. In the months of May to August 2018 , which were the sampling months, the area experienced $67 \%$ northerly winds (39\% north, $13 \%$ north east, and $15 \%$ northwest).

\section{Beehive and Colony Characteristics}

We used Langstroth type beehives with a plastic bottom and pollen trap. The colonies were arranged with a newly raised honeycomb, eight frame hives, and 1year-old queen bee colonies were used, without additional feeding.

\section{Collection and Conservation of Samples}

Pollen: Pollen was collected three times every 15 days in May and June and dried in the dark. Subsequently, $25 \mathrm{~g}$ (total $75 \mathrm{~g}$ ) pollen collected and dried from each colony at once was taken, mixed, placed into glass jars, and stored at $-18^{\circ} \mathrm{C}$ until analysis.

Honey: The honey of each colony was harvested separately between 15 July and 15 August without using a smoker. Approximately $500 \mathrm{~g}$ of honey from each colony was placed in glass jars, and the honeys were kept at room temperature and in the dark until analysis.

Honey bee: After August 15, the entrance hole of each colony was closed before noon (around 09:00 - 10:00), and 30 worker bees returning from the field were caught at the hive entrance using plastic gloves. Samples were placed in glass jars and stored at $-18^{\circ} \mathrm{C}$ until analysis.

\section{Preparation of samples and heavy metal analysis}

Dried pollen was ground to obtain a homogeneous sample (Kacar and İnal 2008). Approximately $2 \mathrm{~g}$ of ground pollen samples and bee samples kept at - $18^{\circ} \mathrm{C}$ were taken and dried in an oven at $70^{\circ} \mathrm{C}$ until constant weight before being used in the analysis.

In the analysis of heavy metals, $0.2 \mathrm{~g}$ of honey, pollen and bee (whole bee) samples obtained from all locations were weighed into heat-resistant Teflon containers. Subsequently, $5 \mathrm{ml}$ of concentrated $\mathrm{HNO}_{3}$ and $2 \mathrm{ml}$ of $\mathrm{H}_{2} \mathrm{O}_{2}(30 \% \mathrm{w} / \mathrm{v})$ were added to the weighed samples, and the samples were thawed in a microwave device under high temperature $\left(210^{\circ} \mathrm{C}\right)$ and pressure $(200 \mathrm{PSI})$. To ensure the reliability of the analysis, one control (blank) and one certified reference sample (Peach Leaves, NIST, SRM 1547) were added into the 40-cell microwave set. The volumes of the thawed samples were made up to $20 \mathrm{ml}$ with deionized water, filtered with blue-banded filter paper, and stored in the refrigerator at $+4^{\circ} \mathrm{C}$ until readings were taken.

The heavy metal contents of the samples (total Pb, Cd, $\mathrm{Cr}, \mathrm{Zn}, \mathrm{Cu}, \mathrm{Ni}, \mathrm{Mn}$, and Fe) were determined using an ICP-AES (Inductively Coupled Plasma Atomic Emission Spectrometry, Varian-Vista Model, Axial) (USDA 2004). Elemental amounts of the samples are given in $\mu \mathrm{g} / \mathrm{kg}$ for $\mathrm{Cd}$ and $\mathrm{Cr}$ and in $\mathrm{mg} / \mathrm{kg}$ for the other elements.

\section{Statistical Analysis}

Heavy metal amounts were determined in five honey bee, honey, and pollen samples taken from each of the eight different locations. The study was carried out in a randomized plot design. The data were subjected to one-way analysis of variance, and Tukey's test was used to determine the differences among groups. Data are presented as mean and standard error.

\section{Results And Discussion}

\section{Heavy metal values in honey samples}

Heavy metal (Cd, $\mathrm{Cr}, \mathrm{Cu}, \mathrm{Fe}, \mathrm{Mn}, \mathrm{Ni}, \mathrm{Pb}$, and $\mathrm{Zn}$ ) mean values and standard errors of honey samples are shown in Table 1. In honey samples, significant statistical differences were found among the locations in terms of $\mathrm{Cr}, \mathrm{Cu}, \mathrm{Fe}, \mathrm{Mn}, \mathrm{Ni}$ and $\mathrm{Zn}$, except $\mathrm{Cd}$ and $\mathrm{Pb},(\mathrm{P}<0.05)$.

The $\mathrm{Cd}$ value of honey samples ranged from $4.301-6.898 \mu \mathrm{g} / \mathrm{kg}$, and the difference among locations was statistically insignificant. Bosancic et al. (2020) stated that no statistically significant differences were found between conventional and organic honey production systems. On the other hand, Arslan 
and Arıkan (2013) found the highest amount of Cd in honey samples taken from stations close to the highway. Adugna et al. (2020) found Cd contents of honey samples from different regions in the range of $17-35 \mu \mathrm{g} / \mathrm{kg}$,which was higher compared with our results.

The maximum Cu content of honey samples was $0.950 \mathrm{mg} / \mathrm{kg}$ at L2, whereas the minimum values was $0.395 \mathrm{mg} / \mathrm{kg}$ at $(\mathrm{L} 7)(\mathrm{P}<0.05)$. Demirezen and Aksoy (2005) found that the Cu content of honey samples taken from sites close to residential areas was higher than those from rural areas (Pख0.01). On the other hand, Silici et al. (2016) stated that there was no statistical difference among the Cu values of honey samples taken from different distances to a thermal power plant.

The Cr, Fe, Mn, Ni, and Zn values of honey samples were highest around the city (L3, $67.01 \mu \mathrm{g} / \mathrm{kg} ; \mathrm{L} 4,67.01 \mu \mathrm{g} / \mathrm{kg} ; \mathrm{L1}, 1,270 \mathrm{mg} / \mathrm{kg} ; \mathrm{L} 3,0.216 \mathrm{mg} / \mathrm{kg} ; \mathrm{L} 4$, $1.635 \mathrm{mg} / \mathrm{kg}$ ) and lowest in the rural sites (L8, $27.70 \mu \mathrm{g} / \mathrm{kg} ; \mathrm{L} 6,6.266 \mathrm{mg} / \mathrm{kg} ; \mathrm{L} 6,0.520 \mathrm{mg} / \mathrm{kg} ; \mathrm{L} 8,0.106 \mathrm{mg} / \mathrm{kg} ; \mathrm{L} 6,1.039 \mathrm{mg} / \mathrm{kg}$ ).

Leblebici (2006) reported that the $\mathrm{Cr}$ content of honey samples taken from sites close to residential areas was higher than that from rural areas ( $<<0.05)$. Gurel et al. (1998) found significant differences among honey samples obtained from different locations in terms of Fe concentration $(P<0.01)$. Leblebici (2006) found the Fe content of honey samples taken from locations close to the city center was higher than that of locations far from the city center $(P<0.05)$. Arslan and Arıkan (2013) did not detect a significant difference among the Mn values of honey samples obtained from colonies placed at different distances from the highway. Taha et al. (2017) found that the Ni content in honey samples taken from colonies placed at different distances to the cement factory was higher in samples close to the factory $(P<0.05)$. Demirezen and Aksoy $(2005)$ stated that the Ni content of honey samples taken from sites close to residential areas was higher than those from rural areas (Pष0.01). Taha et al. (2017) found the Zn content of honey samples taken from colonies placed at different distances from a cement factory was higher in samples close to the factory $(P<0.05)$. The Zn values $(1.039-1.635 \mathrm{mg} / \mathrm{kg})$ obtained in our study were lower than the value $(4.814 \mathrm{mg} \mathrm{kg}$ ) determined by Aliu et al. (2020) in honey.

The $\mathrm{Pb}$ content of honey samples ranged between 0.073 and $0.118 \mathrm{mg} / \mathrm{kg}$, and the differences among the locations were statistically insignificant. On the other hand, Roman (2010) determined that the $\mathrm{Pb}$ content of honey samples obtained from settlements was higher than the values obtained from agriculture and forest areas $(P<0.05)$. The $\mathrm{Pb}$ value $(0.073-0.118 \mathrm{mg} / \mathrm{kg})$ obtained in our study was similar to the value $(0.02-0.098 \mathrm{mg} / \mathrm{kg}) \mathrm{determined} \mathrm{by} \mathrm{Purcarea} \mathrm{et} \mathrm{al.}$ (2017) in Polish honeys.

In our study, the $\mathrm{Cd}$ and $\mathrm{Pb}$ values of honey samples were within the International Food Standard values (Alimentarius 2015).

\section{Heavy metal values in pollen samples}

The mean values and standard errors of $\mathrm{Cd}, \mathrm{Cr}, \mathrm{Cu}, \mathrm{Fe}, \mathrm{Mn}, \mathrm{Ni}, \mathrm{Pb}$, and $\mathrm{Zn}$ in pollen samples are given in Table 2. In pollen samples, the differences among the locations were statistically significant in terms of $\mathrm{Cr}, \mathrm{Cu}, \mathrm{Fe}, \mathrm{Mn}, \mathrm{Ni}, \mathrm{Pb}$, and $\mathrm{Zn}$, except $\mathrm{Cd},(\mathrm{P}<0.05)$.

The Cd contents of the pollen samples ranged between 6.535 and $11.304 \mu \mathrm{g} / \mathrm{kg}$, and the difference among the locations was statistically insignificant. Similarly, Arslan and Arıkan (2013) stated that there was no significant difference among the Cd values of pollen samples taken from colonies placed at different distances from the highway.

The Cd value $(6.535-11.304 \mu \mathrm{g} / \mathrm{kg})$ obtained in our study was lower than the value (26.1- $92.0 \mu \mathrm{g} / \mathrm{kg})$ determined by Formicki et al. (2013) in Poland pollen.

The $\mathrm{Cr}, \mathrm{Cu}, \mathrm{Fe}, \mathrm{Mn}, \mathrm{Ni}$, and $\mathrm{Pb}$ values of pollen samples were highest at sites around the city (L3, 79.36 $\mu \mathrm{gg} / \mathrm{kg} ; \mathrm{L} 4,7.275 \mathrm{mg} / \mathrm{kg} ; \mathrm{L} 4,96.95 \mathrm{mg} / \mathrm{kg} ; \mathrm{L} 1,19.149$ $\mathrm{mg} / \mathrm{kg} ; \mathrm{L} 4,0.384 \mathrm{mg} / \mathrm{kg} ; \mathrm{L} 4,0.180 \mathrm{mg} / \mathrm{kg}$ ) and lowest in the rural sites (L8, $46.10 \mu \mathrm{gg} / \mathrm{kg} ; \mathrm{L} 6,3.915 \mathrm{mg} / \mathrm{kg} ; \mathrm{L} 7,61.40 \mathrm{mg} / \mathrm{kg} ; \mathrm{L6}, 5.356 \mathrm{mg} / \mathrm{kg} ; \mathrm{L} 7,0.218 \mathrm{mg} / \mathrm{kg}$; $\mathrm{L} 8,0.059 \mathrm{mg} / \mathrm{kg})$.

Conti and Botrè (2001) found higher $\mathrm{Cr}$ contents in pollen samples obtained from inner-city locations compared to urban locations $(\mathrm{P}<0.01)$. Taha et al. (2017) found that the Cu content of pollen samples taken from colonies placed at different distances from a cement factory was higher in samples close to the factory $(P<0.05)$. Taha (2015) found significant statistical differences among pollen obtained from different plants in terms of Fe content $(P<0.05)$. Arslan and Arıkan (2013) did not find a significant statistical difference among the Fe values of pollen samples obtained from colonies placed at different distances from the highway. Fakhimzadeh and Lodenius (2000) found no significant statistical difference among industrial, urban, and rural areas in terms of Mn values in pollen samples. Taha et al. (2017) found that the Ni content in the pollen samples taken from the colonies placed at different distances to a cement factory was higher in the samples close to the factory $(P<0.05)$. Conti and Botrè $(2001)$ found higher Pb contents of pollen samples taken from the colonies in the city center compared to those from colonies around the city $(\mathrm{P}<0.01)$.

The $\mathrm{Zn}$ content of the pollen samples was highest in the urban location (L3), with $20.27 \mathrm{mg} / \mathrm{kg}$ and lowest in the rural location (L7), with 10.25 mg/kg $(P<0.05)$. On the other hand, Arslan and Arıkan (2013) did not detect significant statistical differences among the $\mathrm{Zn}$ values of pollen samples obtained from colonies placed at different distances from the highway.

The $\mathrm{Zn}$ value (10.25-20.27 mg/kg) obtained in our study was lower than the value (75.2- $159.3 \mu \mathrm{g} / \mathrm{g}$ ) determined by Formicki et al. (2013) from Poland pollen. Altunatmaz et al. (2017) stated that mineral levels are related to plant type rather than to the soil and geographical situation.

\section{Heavy metal results in honey bee samples}

Heavy metals (Cd, $\mathrm{Cr}, \mathrm{Cu}, \mathrm{Fe}, \mathrm{Mn}, \mathrm{Ni}, \mathrm{Pb}$ and $\mathrm{Zn}$; mean values and standard errors) of honey bee samples are summarized in Table 3. 
The Cd content of honey bee samples was highest in the site around the city ( $L 4)$, with $20.78 \mu \mathrm{g} / \mathrm{kg}$, and lowest at the rural site ( $\mathrm{L} 8)$, with $9.52 \mu \mathrm{g} / \mathrm{kg}(\mathrm{P}<0.05)$. Similar results were found by Conti and Botrè (2001), where the $\mathrm{Cd}$ content of bee samples obtained from the inner-city location was higher than that from the surrounding locations $(\mathrm{P}<0.01)$. Similarly, Fakhimzadeh and Lodenius $(2000)$ found a higher $\mathrm{Cd}$ content of bee samples taken from urban and industrial areas compared to samples from rural areas $(P<0.05)$. The $C d$ values $(9.52-20.78 \mu \mathrm{g} / \mathrm{kg})$ obtained in our study were lower than the range $(0.03-0.30 \mathrm{mg} / \mathrm{kg})$ determined by Goretti et al. (2020).

The Cr content of honey bee samples was highest, at $99.24 \mu \mathrm{g} / \mathrm{kg}$, in the urban site (L3) and lowest, at $58.24 \mu \mathrm{g} / \mathrm{kg}$, in the rural site (L7) ( $<<0.05)$. Gutiérrez et al. (2015) found the highest $\mathrm{Cr}$ contents in honey bee samples taken from different locations, including urban, industrial, agricultural, and forested areas (P®0.01).

In this study, the Cu content of honey bee samples was highest in the site around the city (L3), with $17.18 \mathrm{mg} / \mathrm{kg}$, and lowest at the rural site (L6), with 12.18 $\mathrm{mg} / \mathrm{kg}(\mathrm{P}<0.05)$. Roman (2010) found that the Cu contents of honey bee samples obtained from residential areas were higher than those obtained from agricultural and forest areas $(P<0.05)$. Silici et al. (2016), on the other hand, did not detect a statistical difference among the Cu values of honey bee samples taken at different distances to a thermal power plant.

Te Fe contents of honey bee samples were highest at the site around the city (L3), with $101.81 \mathrm{mg} / \mathrm{kg}$, and lowest at the rural site (L6), with $82.46 \mathrm{mg} / \mathrm{kg}$ $(\mathrm{P}<0.05)$. Nisbet et al. (2013) reported that the Fe content of honey bee samples taken from locations with different environmental and flora characteristics varied from region to region $(P<0.05)$. Taha et al. (2017) found that the Fe contents in honey bee samples taken from colonies placed at different distances to a cement factory were higher in samples close to the factory $(P<0.05)$.

The Mn contents of honey bee samples were highest at the site around the city (L1), with $35.55 \mathrm{mg} / \mathrm{kg}$, and lowest at the rural location (L6), with 15.63 mg/kg $(\mathrm{P}<0.05)$. On the other hand, Silici et al. (2016) did not detect a statistical difference among the Mn values of honey bee samples taken at different distances to a thermal power plant.

The Ni values of honey bee samples were highest at the site around the city (L3), with $0.432 \mathrm{mg} / \mathrm{kg}$, and the lowest at the rural location (L7), with $0.201 \mathrm{mg} / \mathrm{kg}$ $(P<0.05)$. Nisbet et al. (2013) found a statistical difference among the Ni contents of honey bee samples obtained from locations with different environmental and floral characteristics $(P<0.05)$.

The $\mathrm{Pb}$ contents of honey bee samples were highest at the site around the city (L3), with $0.358 \mathrm{mg} / \mathrm{kg}$, and lowest at the rural site (L8), with $0.192 \mathrm{mg} / \mathrm{kg}$ $(\mathrm{P}<0.05)$. Roman (2010) found higher $\mathrm{Pb}$ levels of honey bee samples in residential areas compared to agricultural and forest areas $(\mathrm{P}<0.05)$. The $\mathrm{Pb}$ values $(0.192-0.358 \mathrm{mg} / \mathrm{kg})$ obtained in our study were lower than those $(4-27 \mu \mathrm{g} / \mathrm{g})$ determined by Leita et al. (1996). On the other hand, our values were similar to those $(0.14-0.52 \mathrm{mg} / \mathrm{kg})$ determined by Perugini et al. (2011).

The $\mathrm{Zn}$ contents of honey bee samples were highest at the site around the city (L4), with $44.58 \mathrm{mg} / \mathrm{kg}$, and lowest at the rural location ( $\mathrm{L} 8$ ), with $29.93 \mathrm{mg} / \mathrm{kg}$ $(P<0.05)$. Nisbet et al. (2013) reported that the $Z n$ values of honey bee samples taken from locations with different environmental and floral characteristics varied from region to region $(P<0.05)$, In a similar study, Taha et al. (2017), analyzing honey bee samples from colonies placed at different distances to a cement factory, found higher $\mathrm{Zn}$ values in the samples closer to the factory $(P<0.05)$.

\section{Conclusions}

There were no statistical differences among the locations in terms of $\mathrm{Cd}$ and $\mathrm{Pb}$ in honey samples. However, the $\mathrm{Cr}, \mathrm{Cu}, \mathrm{Fe}, \mathrm{Mn}, \mathrm{Ni}$, and $\mathrm{Zn}$ values were lower in samples from rural areas.

Regarding the pollen samples, we observed significant differences among the locations in terms of $\mathrm{Cr}, \mathrm{Cu}, \mathrm{Fe}, \mathrm{Mn}, \mathrm{Ni}, \mathrm{Pb}$, and $\mathrm{Zn}$, with values being lower in rural than in urban areas. The $\mathrm{Cd} \mathrm{Cr}, \mathrm{Cu}, \mathrm{Fe}, \mathrm{Mn}, \mathrm{Ni}, \mathrm{Pb}$, and $\mathrm{Zn}$ values of honey bee samples were also lower in rural than in urban areas.

The $\mathrm{Cd}$ and $\mathrm{Pb}$ values of honey and pollen samples were in agreement with the International Food Standard values (Alimentarius, 2015). To obtain healthy bees and bee products, it is recommended that the colonies are placed away from residential areas, industrial areas, highways, polluted water sources, and areas where bee products are likely to be subjected to contamination.

\section{Declarations}

\section{Ethical Approval}

Not applicable

\section{Consent to Participate}

Not applicable

\section{Consent to Publish}

Not applicable

\section{Author Contributions}


Study conception, study design, material preparation, data collection, analysis and writing were performed by Huseyin Bayir.

Study conception, study design, analysis, writing and editting were performed by Ali Aygun.

\section{Funding}

This work was supported by Selcuk University Scientific Research Projects Coordinator (Grant number; 18101008)

\section{Competing Interests}

The authors have no competing interests to declare that are relevant to the content of this article

\section{Availability of data and materials}

The datasets used and/or analyzed during the present study are available from the corresponding author on reasonable request.

Acknowledgements: This study is a summary of a part of Huseyin Bayir's doctoral thesis. This work was supported by Selcuk University Scientific Research Projects Coordinator (Grant number; 18101008)

\section{References}

1. Adugna E, Hymete A, Birhanu G, Ashenef A (2020) Determination of some heavy metals in honey from different regions of Ethiopia. Cogent Food Agric 6: 1764182. https://doi.org/10.1080/23311932.2020.1764182

2. Ahmida NH, Elagori M, Agha A, Elwerfali S, Ahmida MH (2012) Physicochemical, heavy metals and phenolic compounds analysis of Libyan honey samples collected from Benghazi during 2009-2010. Food Nutr Sci 4: 33-40. https://doi.org/10.4236/fns.2013.41006

3. Alimentarius (2015): General standard for contaminants and toxins in food and feed (Codex STAN 193-1995), International Food Standards

4. Aliu H, Makolli S, Dizman S, Kadiri S, Hodolli G (2020) Impact of environmental conditions on heavy metal concentration in honey samples. J Environ Prot Ecol 21: 351-358.

5. Altunatmaz SS, Tarhan D, Aksu F, Barutçu UB, Mehmet E (2017) Mineral element and heavy metal (cadmium, lead and arsenic) levels of bee pollen in Turkey. Food Sci Technol 37: 136-141. https://doi.org/10.1590/1678-457X.36016

6. Arslan S, Arıkan A (2013) Accumulation of heavy metals in bee products effect of distance from highway. Turkish Journal of Agriculture-Food Science and Technology 1: 90-93. https://doi.org/10.24925/turjaf.v1i2.90-93.38

7. Bogdanov S (2008): Contaminants of Bee Producs. In: Öztürk Ai , Doğaroğlu M (Hrsg.), $1^{\text {st }}$ International Muğla Beekeeping and Pine Honey Congress. Muğla University, Muğla, Turkey, pp. 82-95

8. Bosancic B, Zabic M, Mihajlovic D, Samardzic J, Mirjanic G (2020) Comparative study of toxic heavy metal residues and other properties of honey from different environmental production systems. Environ Sci Pollut Res 27: 38200-38211. https://doi.org/10.1007/s11356-020-09882-y

9. Conti ME, Botrè F (2001) Honeybees and their products as potential bioindicators of heavy metals contamination. Environ Monit Assess 69: $267-282$. https://doi.org/10.1023/A:1010719107006

10. Costa-Silva F, Maia M, Matos CC, Calçada E, Barros Al, Nunes FM (2011) Selenium content of Portuguese unifloral honeys. J Food Compost Anal 24: 351 355. https://doi.org/10.1016/j.jfca.2010.09.019

11. Demirezen D, Aksoy A (2005) Determination of heavy metals in bee honey using by inductively coupled plasma optical emission spectrometry (ICP-OES). Gazi University Journal of Science 18: 569-575.

12. Duruibe JO, Ogwuegbu M, Egwurugwu J (2007) Heavy metal pollution and human biotoxic effects. International Journal of physical sciences 2: $112-118$.

13. Fakhimzadeh K, Lodenius M (2000) Honey, pollen and bees as Indicator of heavy metal pollution. https://doi.org/10.1016/j.scitotenv.2018.07.128

14. Formicki G, Gren A, Stawarz R, Zysk B, Gal A (2013) Metal Content in Honey, Propolis, Wax, and Bee Pollen and Implications for Metal Pollution Monitoring. Pol J Environ Stud 22: 99-106.

15. Goretti E, Pallottini M, Rossi R, La Porta G, Gardi T, Cenci Goga BT, Elia AC, Galletti M, Moroni B, Petroselli C, Selvaggi R, Cappelletti D (2020) Heavy metal bioaccumulation in honey bee matrix, an indicator to assess the contamination level in terrestrial environments. Environ Pollut 256: 113388. https://doi.org/10.1016/j.envpol.2019.113388

16. Gurel F, Karkacier M, Ozdemir F (1998) Identification of sugar honey, multifloral honey and honeydew honey based on mineral content, total ash, pH and acidity. Apiatica 33: 42-45.

17. Gutiérrez M, Molero R, Gaju M, van der Steen J, Porrini C, Ruiz JA (2015) Assessment of heavy metal pollution in Córdoba (Spain) by biomonitoring foraging honeybee. Environ Monit Assess 187: 1-15. https://doi.org/10.1007/s10661-015-4877-8

18. Hennessy S, Downey G, O'Donnell CP (2010) Attempted confirmation of the provenance of Corsican PDO honey using FT-IR spectroscopy and multivariate data analysis. J Agric Food Chem 58: 9401-9406. https://doi.org/10.1021/jf101500n

19. Kacar B, İnal A (2008): Bitki analizleri, 2. Nobel Akademik, Ankara, 892 (in Turkish) pp

20. Leblebici Z (2006) Determination of heavy metal pollution in some honey samples from Kayseri province. Master Thesis, Erciyes University, Kayseri, Turkey (in Turkish)

21. Leita L, Muhlbachova G, Cesco S, Barbattini R, Mondini C (1996) Investigation of the use of honey bees and honey bee products to assess heavy metals contamination. Environ Monit Assess 43: 1-9. https://doi.org/10.1007/BF00399566

Page 6/9 
22. Nisbet C, Güler A, Yarım GF, Cenesiz S, Ardalı Y (2013) Relationship between environmental and flora change with mineralk content of honey bee products. Turk J Biochem 38: 494-498. http://dx.doi.org/10.5505/tjb.2013.07269

23. Özbolat G, Abdullah T (2016) Effects of heavy metal toxicityon human health. Arch Rev J 25: 502-521. doi:10.17827/aktd.253562 (in Turkish)

24. Perugini M, Manera M, Grotta L, Abete MC, Tarasco R, Amorena M (2011) Heavy metal ( $\mathrm{Hg}$, Cr, Cd, and Pb) contamination in urban areas and wildlife reserves: honeybees as bioindicators. Biol Trace Elem Res 140: 170-176. https://doi.org/10.1007/s12011-010-8688-z

25. Pohl P, Sergiel I, Prusisz B (2011) Direct analysis of honey for the total content of Zn and its fractionation forms by means of flame atomic absorption spectrometry with solid phase extraction and ultrafiltration approaches. Food Chem 125: 1504-1509. https://doi.org/10.1016/j.foodchem.2010.10.077

26. Porrini C, Sabatini AG, Girotti S, Ghini S, Medrzycki P, Grillenzoni F, Bortolotti L, Gattavecchia E, Celli G (2003) Honey bees and bee products as monitors of the environmental contamination. Apiacta 38: 63-70.

27. Purcarea C, Dzugan M, Wesolowska M, Chis AM, Zagula G, Teusdea AC, Puchalski C (2017) A comparative study of metal content in selected polish and romanian honey samples. Rev Chim 68: 1163-1169. https://doi.org/10.37358/RC.17.6.5634

28. Roman A (2010) Levels of Copper, Selenium, Lead, and Cadmium in Forager Bees. Pol J Environ Stud 19.

29. Silici S, Uluozlu OD, Tuzen M, Soylak M (2016) Honeybees and honey as monitors for heavy metal contamination near thermal power plants in Mugla, Turkey. Toxicol Ind Health 32: 507-516. https://doi.org/10.1177/0748233713503393

30. Squadrone S, Brizio P, Stella C, Mantia M, Pederiva S, Brusa F, Mogliotti P, Garrone A, Abete MC (2020) Trace elements and rare earth elements in honeys from the Balkans, Kazakhstan, Italy, South America, and Tanzania. Environ Sci Pollut Res 27: 12646-12657. https://doi.org/10.1007/s11356-020-07792-7

31. Taha E-KA (2015) Chemical composition and amounts of mineral elements in honeybee-collected pollen in relation to botanical origin. J Apic Sci 59: 7581. https://doi.org/10.1515/jas-2015-0008

32. Taha E-KA, Al-Jabr AM, Al-Kahtani SN (2017) Honey Bees, Bee-collected pollen and honey as monitors of environmental pollution at an industrial cement area in Saudi Arabia. J Kans Entomol Soc 90: 1-10. https://doi.org/10.2317/151230.1

33. Tuzen M, Silici S, Mendil D, Soylak M (2007) Trace element levels in honeys from different regions of Turkey. Food Chem 103: 325-330. https://doi.org/10.1016/j.foodchem.2006.07.053

34. Türközü D, Şanlıer N (2014) Heavy metal contamination of food: sources of contamination, health risks and national/ınternational standards. Electron J Food Technol 9: 29-46 (in Turkish).

35. Uluozlu OD, Tuzen M, Mendil D, Soylak M (2007) Trace metal content in nine species of fish from the Black and Aegean Seas, Turkey. Food Chem 104: 835-840. https://doi.org/10.1016/j.foodchem.2007.01.003

36. USDA (2004): Soil Survey Laboratory Methods Manual. U. S. Department of Agriculture, Washington, DC

37. Yılmaz N (1996) Elemental analysis in honey and pollen samples collected from Izmit region and pollen analysis in honey samples. Master Thesis, Hacettepe University, Ankara, Turkey (in Turkish)

38. Zhelyazkova I (2012) Honeybees-bioindicators for environmental quality. Bulg J Agric Sci 18: 435-442.

\section{Tables}

Table 1 Heavy metalcontents of honey samples

\begin{tabular}{|c|c|c|c|c|c|c|c|c|}
\hline Locations & $\mathrm{Cd}(\mu \mathrm{g} / \mathrm{kg})$ & $\mathrm{Cr}(\mu \mathrm{g} / \mathrm{kg})$ & $\mathrm{Cu}(\mathrm{mg} / \mathrm{kg})$ & $\mathrm{Fe}(\mathrm{mg} / \mathrm{kg})$ & $\mathrm{Mn}(\mathrm{mg} / \mathrm{kg})$ & $\mathrm{Ni}(\mathrm{mg} / \mathrm{kg})$ & $\mathrm{Pb}(\mathrm{mg} / \mathrm{kg})$ & $\mathrm{Zn}(\mathrm{mg} / \mathrm{kg})$ \\
\hline L1 & $6.509 \pm 0.642$ & $43.63 \pm 3.634^{\mathrm{bc}}$ & $0.676 \pm 0.073^{\mathrm{abc}}$ & $6.880 \pm 0.711^{\mathrm{b}}$ & $1.270 \pm 0.116^{\mathrm{a}}$ & $0.185 \pm 0.010^{\mathrm{abc}}$ & $0.102 \pm 0.007$ & $1.289 \pm 0.071^{a b}$ \\
\hline L2 & $5.849 \pm 0.853$ & $42.77 \pm 1.679^{\mathrm{bc}}$ & $0.950 \pm 0.073^{a}$ & $6.753 \pm 0.580^{\mathrm{b}}$ & $0.712 \pm 0.030^{c}$ & $0.203 \pm 0.012^{\mathrm{ab}}$ & $0.115 \pm 0.007$ & $1.378 \pm 0.069^{a b}$ \\
\hline L3 & $6.625 \pm 0.701$ & $67.01 \pm 6.194^{a}$ & $0.612 \pm 0.037^{b c}$ & $10.000 \pm 1.076^{\mathrm{ab}}$ & $0.784 \pm 0.050^{\mathrm{bc}}$ & $0.216 \pm 0.016^{a}$ & $0.118 \pm 0.010$ & $1.606 \pm 0.114^{\mathrm{a}}$ \\
\hline L4 & $6.898 \pm 0.447$ & $60.40 \pm 4.943^{\mathrm{ab}}$ & $0.821 \pm 0.050^{\mathrm{ab}}$ & $14.500 \pm 1.577^{a}$ & $1.152 \pm 0.110^{\mathrm{ab}}$ & $0.210 \pm 0.021^{\mathrm{ab}}$ & $0.118 \pm 0.014$ & $1.635 \pm 0.116^{a}$ \\
\hline L5 & $5.803 \pm 0.574$ & $39.13 \pm 1.864^{c}$ & $0.541 \pm 0.054^{\mathrm{bc}}$ & $7.915 \pm 0.922^{b}$ & $0.694 \pm 0.058^{c}$ & $0.137 \pm 0.015^{\mathrm{bcd}}$ & $0.079 \pm 0.010$ & $1.159 \pm 0.054^{\mathrm{b}}$ \\
\hline L6 & $4.861 \pm 0.645$ & $42.57 \pm 4.007^{\mathrm{bc}}$ & $0.446 \pm 0.034^{c}$ & $6.266 \pm 0.514^{b}$ & $0.520 \pm 0.058^{c}$ & $0.137 \pm 0.014^{\mathrm{bcd}}$ & $0.092 \pm 0.007$ & $1.039 \pm 0.070^{\mathrm{b}}$ \\
\hline L7 & $4.301 \pm 0.682$ & $36.85 \pm 3.217^{c}$ & $0.395 \pm 0.031^{c}$ & $6.744 \pm 0.656^{b}$ & $0.564 \pm 0.041^{c}$ & $0.124 \pm 0.010^{\mathrm{cd}}$ & $0.079 \pm 0.005$ & $1.148 \pm 0.075^{\mathrm{b}}$ \\
\hline L8 & $4.816 \pm 0.339$ & $27.70 \pm 2.187^{c}$ & $0.533 \pm 0.055^{\mathrm{bc}}$ & $6.326 \pm 0.819^{b}$ & $0.710 \pm 0.071^{c}$ & $0.106 \pm 0.011^{d}$ & $0.073 \pm 0.009$ & $1.158 \pm 0.025^{b}$ \\
\hline$P$ value & 0.059 & 0.000 & 0.000 & 0.000 & 0.000 & 0.000 & 0.001 & 0.000 \\
\hline
\end{tabular}

${ }^{a-d}$ Different letters in the same column indicate significant differences $(P<0.05)$.

Table 2 Heavy metalcontents of pollen samples 


\begin{tabular}{|c|c|c|c|c|c|c|c|c|}
\hline Locations & $\mathrm{Cd}(\mu \mathrm{g} / \mathrm{kg})$ & $\mathrm{Cr}(\mu \mathrm{g} / \mathrm{kg})$ & $\mathrm{Cu}(\mathrm{mg} / \mathrm{kg})$ & $\mathrm{Fe}(\mathrm{mg} / \mathrm{kg})$ & Mn (mg/kg) & $\mathrm{Ni}(\mathrm{mg} / \mathrm{kg})$ & $\mathrm{Pb}(\mathrm{mg} / \mathrm{kg})$ & $\mathrm{Zn}(\mathrm{mg} / \mathrm{kg})$ \\
\hline L1 & $10.426 \pm 0.981$ & $69.71 \pm 3.475^{a b}$ & $5.600 \pm 0.378^{\mathrm{abc}}$ & $73.18 \pm 5.362^{a b}$ & $19.149 \pm 0.424^{\mathrm{a}}$ & $0.338 \pm 0.017^{a b}$ & $0.108 \pm 0.004^{\mathrm{cd}}$ & $15.10 \pm 0.757^{b}$ \\
\hline L2 & $9.848 \pm 1.514$ & $75.51 \pm 5.626^{a b}$ & $5.685 \pm 0.223^{\mathrm{ab}}$ & $80.99 \pm 6.902^{\mathrm{ab}}$ & $10.153 \pm 0.623^{c}$ & $0.321 \pm 0.030^{\mathrm{ab}}$ & $0.123 \pm 0.010^{b c}$ & $18.75 \pm 0.760^{\mathrm{a}}$ \\
\hline L3 & $11.304 \pm 1.331$ & $79.36 \pm 6.060^{\mathrm{a}}$ & $6.355 \pm 0.288^{\mathrm{ab}}$ & $95.32 \pm 8.379^{a b}$ & $18.603 \pm 0.846^{a}$ & $0.370 \pm 0.036^{a b}$ & $0.171 \pm 0.012^{\mathrm{ab}}$ & $20.27 \pm 0.539^{a}$ \\
\hline L4 & $10.567 \pm 0.712$ & $75.76 \pm 8.980^{\mathrm{ab}}$ & $7.275 \pm 0.473^{a}$ & $96.95 \pm 4.494^{a}$ & $13.312 \pm 0.494^{b}$ & $0.384 \pm 0.032^{\mathrm{a}}$ & $0.180 \pm 0.009^{a}$ & $19.52 \pm 0.376^{a}$ \\
\hline L5 & $9.343 \pm 0.694$ & $64.96 \pm 4.808^{a b}$ & $5.430 \pm 0.298^{b c}$ & $89.93 \pm 6.951^{\mathrm{ab}}$ & $9.789 \pm 0.716^{c}$ & $0.247 \pm 0.027^{a b}$ & $0.097 \pm 0.012^{\mathrm{cd}}$ & $17.89 \pm 0.388^{a b}$ \\
\hline L6 & $9.328 \pm 1.127$ & $58.08 \pm 3.582^{\mathrm{ab}}$ & $3.915 \pm 0.252^{c}$ & $72.70 \pm 5.600^{\mathrm{ab}}$ & $5.356 \pm 0.299^{d}$ & $0.284 \pm 0.037^{\mathrm{ab}}$ & $0.101 \pm 0.009^{c d}$ & $11.59 \pm 0.338^{c}$ \\
\hline L7 & $6.535 \pm 0.771$ & $56.47 \pm 7.630^{\mathrm{ab}}$ & $5.260 \pm 0.318^{b c}$ & $61.40 \pm 5.642^{b}$ & $5.746 \pm 0.454^{d}$ & $0.218 \pm 0.018^{b}$ & $0.083 \pm 0.008^{\mathrm{cd}}$ & $10.25 \pm 0.197^{c}$ \\
\hline L8 & $8.983 \pm 1.023$ & $46.10 \pm 3.855^{b}$ & $5.405 \pm 0.227^{b c}$ & $71.45 \pm 6.923^{\mathrm{ab}}$ & $7.137 \pm 0.424^{\mathrm{cd}}$ & $0.280 \pm 0.035^{\mathrm{ab}}$ & $0.059 \pm 0.005^{d}$ & $10.48 \pm 0.788^{c}$ \\
\hline$P$ value & 0.111 & 0.003 & 0.000 & 0.003 & 0.000 & 0.000 & 0.000 & 0.000 \\
\hline
\end{tabular}

${ }^{a-d}$ Different letters in the same column indicate significant differences $(P<0.05)$.

Table 3 Heavy metalcontents of honey bee samples

\begin{tabular}{|c|c|c|c|c|c|c|c|c|}
\hline Locations & $\mathrm{Cd}(\mu \mathrm{g} / \mathrm{kg})$ & $\mathrm{Cr}(\mu \mathrm{g} / \mathrm{kg})$ & $\mathrm{Cu}(\mathrm{mg} / \mathrm{kg})$ & $\mathrm{Fe}(\mathrm{mg} / \mathrm{kg})$ & $\mathrm{Mn}(\mathrm{mg} / \mathrm{kg})$ & $\mathrm{Ni}(\mathrm{mg} / \mathrm{kg})$ & $\mathrm{Pb}(\mathrm{mg} / \mathrm{kg})$ & $\mathrm{Zn}(\mathrm{mg} / \mathrm{kg})$ \\
\hline L1 & $17.48 \pm 0.744^{\mathrm{ab}}$ & $66.30 \pm 2.138^{b}$ & $13.42 \pm 1.059^{\mathrm{ab}}$ & $91.59 \pm 1.579^{a b}$ & $35.55 \pm 1.759^{a}$ & $0.362 \pm 0.022^{\mathrm{ab}}$ & $0.320 \pm 0.023^{\mathrm{ab}}$ & $42.01 \pm 2.279^{a}$ \\
\hline L2 & $18.50 \pm 1.067^{a}$ & $69.79 \pm 5.443^{b}$ & $14.77 \pm 1.067^{\mathrm{ab}}$ & $100.39 \pm 3.757^{a}$ & $24.31 \pm 1.492^{b c}$ & $0.372 \pm 0.021^{\mathrm{ab}}$ & $0.330 \pm 0.021^{\mathrm{ab}}$ & $35.25 \pm 1.509^{a b}$ \\
\hline L3 & $19.20 \pm 1.058^{a}$ & $99.24 \pm 3.247^{a}$ & $17.18 \pm 0.911^{a}$ & $101.81 \pm 2.102^{\mathrm{a}}$ & $28.08 \pm 1.429^{a b}$ & $0.432 \pm 0.021^{a}$ & $0.358 \pm 0.019^{a}$ & $43.83 \pm 2.529^{a}$ \\
\hline L4 & $20.78 \pm 0.916^{a}$ & $98.54 \pm 3.613^{a}$ & $14.90 \pm 1.128^{\mathrm{ab}}$ & $99.72 \pm 3.318^{a}$ & $34.71 \pm 2.140^{a}$ & $0.417 \pm 0.021^{\mathrm{ab}}$ & $0.333 \pm 0.019^{\mathrm{ab}}$ & $44.58 \pm 2.998^{a}$ \\
\hline L5 & $12.98 \pm 0.623^{b c}$ & $68.42 \pm 3.421^{b}$ & $13.93 \pm 0.795^{\mathrm{ab}}$ & $96.34 \pm 3.287^{a b}$ & $25.67 \pm 1.257^{b}$ & $0.315 \pm 0.017^{b c}$ & $0.315 \pm 0.020^{\mathrm{ab}}$ & $33.68 \pm 1.433^{a b}$ \\
\hline L6 & $13.25 \pm 0.706^{b c}$ & $64.20 \pm 3.452^{b}$ & $12.18 \pm 1.132^{b}$ & $82.46 \pm 4.651^{b}$ & $15.63 \pm 1.182^{c}$ & $0.343 \pm 0.022^{\mathrm{abc}}$ & $0.251 \pm 0.016^{b c}$ & $35.12 \pm 2.458^{a b}$ \\
\hline L7 & $12.41 \pm 0.786^{c}$ & $58.24 \pm 3.511^{b}$ & $13.16 \pm 0.710^{\mathrm{ab}}$ & $85.43 \pm 2.737^{a b}$ & $22.20 \pm 1.699^{b c}$ & $0.201 \pm 0.017^{d}$ & $0.231 \pm 0.016^{\mathrm{bc}}$ & $32.73 \pm 1.957^{\mathrm{ab}}$ \\
\hline L8 & $9.52 \pm 0.623^{c}$ & $58.69 \pm 4.119^{b}$ & $13.01 \pm 1.181^{\mathrm{ab}}$ & $85.31 \pm 1.494^{\mathrm{ab}}$ & $24.02 \pm 1.653^{b c}$ & $0.238 \pm 0.017^{\mathrm{cd}}$ & $0.192 \pm 0.020^{c}$ & $29.93 \pm 1.767^{b}$ \\
\hline$P$ value & 0.000 & 0.000 & 0.047 & 0.000 & 0.000 & 0.000 & 0.000 & 0.000 \\
\hline
\end{tabular}

${ }^{a-d}$ Different letters in the same column indicate significant differences $(P<0.05)$.

\section{Figures}




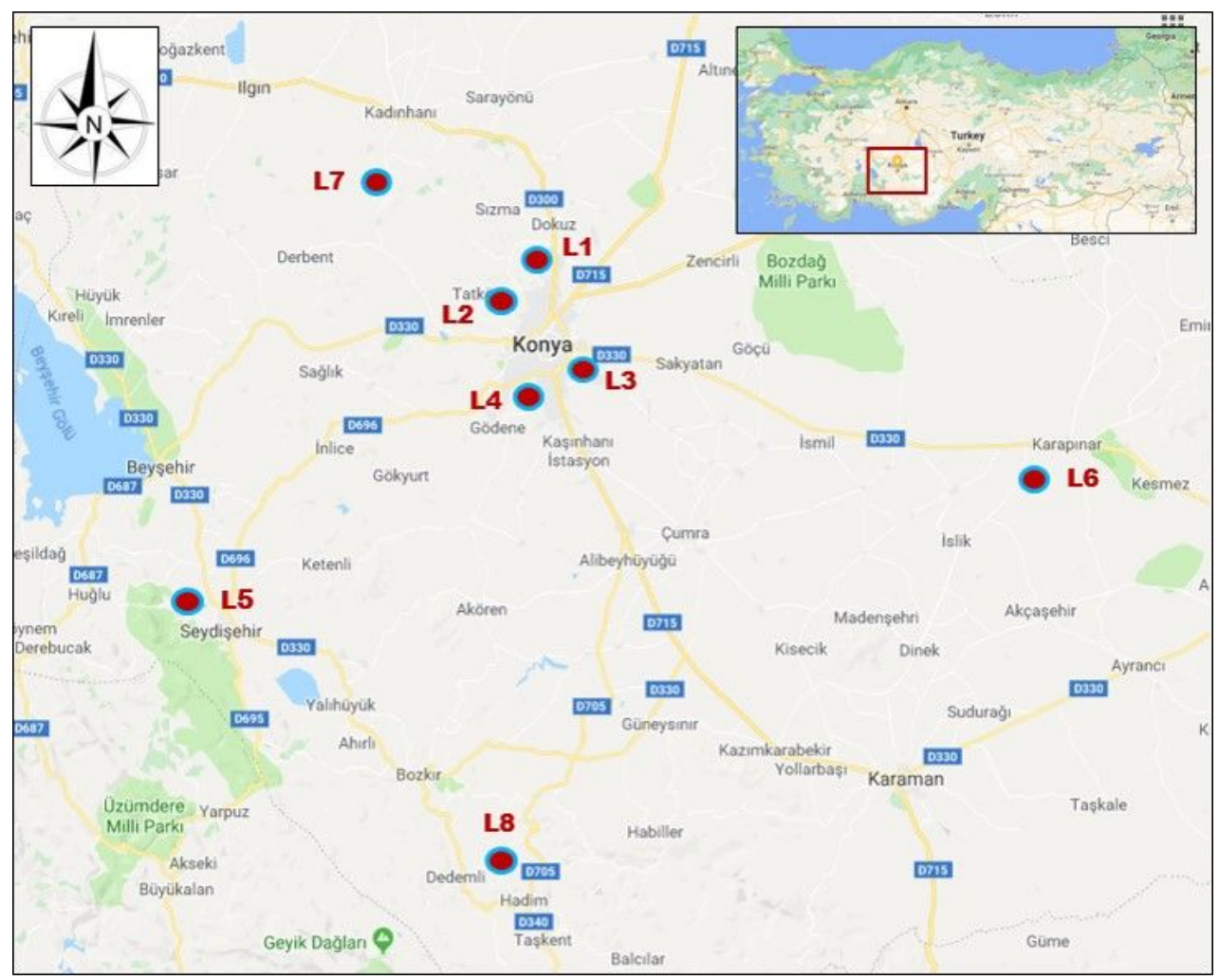

Figure 1

Locations of the honey bee colonies (sampling sites). 